\title{
MEKANISME PASAR PERSPEKTIF ISLAM
}

\author{
Abd. Ghafur*
}

\begin{abstract}
The market is a place that has rules that are prepared to exchange property rights and exchange goods between producers and consumers. Islam affirms that the market must stand on the principle of perfect competition. However, that does not mean that freedom is absolute, but freedom is wrapped in a shari'ah frame. The market mechanism in Islam is the existence of market freedom in determining prices. Prices depend on the market. However, Islam does not adhere to market-based prices freely. Islam will intervene when there is a monopoly on the market price. the market mechanism in an Islamic perspective is not only social dimensioned, but also there is a theological element that the market is controlled and supervised by the Shari'a.
\end{abstract}

Keywords: Mechanism, Market, Islam

* Dosen Institut Ilmu Keislaman Zainul Hasan Genggong Kraksaan Probolinggo 


\section{PENDAHULUAN}

Islam adalah agama yang yang selain bersifat syumuliyah (sempurna) juga harakiyah (dinamis). Disebut sempurna karena Islam merupakan agama penyempurna dari agama-agama sebelumnya dan syari'atnya mengatur selurh aspek kehidupan, baik yang bersifat aqidah maupun muamala. Dalam kaidah tentang mualamah, Islam mengatur segala bentuk perilaku manusia dalam berhubungan dengan sesamanya untuk memenuhi kebutuhan hidupnya di dunia. Termasuk didalamnya adalah kaidah Islam yang mengatur tentang ekonomi dan mekanismenya.

Salah satu sistem ekonomi di zaman Nabi Muhammad saw. yang patut dijakan panutan untuk diaplikasikan dalam kehidupan moderan saat ini adalah pasar (al-suq). Pasar adalah tempat dimana antara penjual dan pembeli bertemu dan melakukan transaksi jual beli barang dan atau jasa. Pasar mempunyai peran yang besar dalam ekonomi.

Pasar adalah tempat yang mempunyai aturan yang disiapkan untuk tukar-menukar hak milik dan menukar barang antara produsen dan konsumen. Di pasar orang bisa mendapatkan kebutuhannya dan tidak ada orang yang tidak memerlukan pasar. Masyarakat saat ini seakan merindukan sebuah sistem pasar yang tepat sebagai bagian dari penolakan pada sistem Kapitalis dan Sosialis yang mengalami kegagalan dalam menciptkan kesejahteraan.

Secara umum, kedua sistem ekonomi tersebut tidak sepenuhnya bertentangan dengan nilai-nilai Islam, namun Islam hendak menempatkan segala sesuatu sesuai pada posisinya, tidak ada yang dirugikan, dan dapat mencerminkan sebagai bagian dari kehidupan holistik dunia dan akhirat.

Konsep Islam menegaskan bahwa pasar harus berdiri di atas prinsip persaingan sempurna (perfect competition). Namun demikian bukan berarti kebebasan tersebut berlaku mutlak, akan tetapi kebebasan yang dibungkus oleh freme (kerangka) syari'ah. Dalam Islam, transaksi terjadi secara sukarela (antaradim minkum)

Sebagaimna disebutkan dalam al-Qur'an surat An-Nisa': 29.

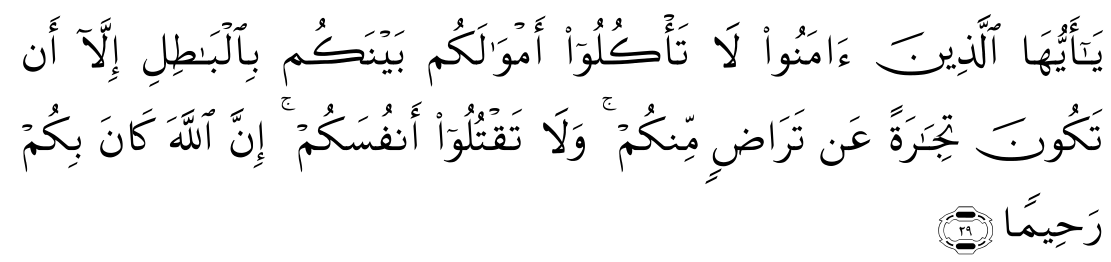


Hai orang-orang yang beriman, janganlab kamu saling memakan harta sesamamu dengan jalan yang batil, kecuali dengan jalan perniagaan yang Berlaku dengan suka sama-suka di antara kamu. dan janganlab kamu membunub dirimu.Sesunggubnya Allah adalah Maha Penyayang kepadamu. (Q.S. An-Nisa':29) ${ }^{1}$

\section{PEMBAHASAN}

\section{A. Pengertian Pasar pada Umumnya}

Pasar secara sederhana merupakan tempat pertemuan antara penjual dan pembeli untuk melakukan transaksi jual beli-beli barang dan jasa. ${ }^{2}$ Adapun pasar menurut kajian ilmu ekonomi memiliki pengertian; Pasar adalah tempat atau keadaan yang mempertemukan antara permintaan (pembeli) atau penawaran (penjual) untuk setiap jenis barang, jasa atau sumber daya. Pembeli meliputi konsumen yang membutuhkan barang dan jasa, sedangkan bagi industri membutuhkan tenaga kerja, modal dan barang baku produksi baik untuk memproduksi barang maupun jasa. Penjual termasuk juga industri menawarkan hasil produk atau jasa yang diminta oleh pembeli; pekerja menjual tenaga dan keahliannya, pemilik lahan menyewakan atau menjual asetnya, sedangkan pemilik modal menawarkan pembagian keuntungan dari kegiatan bisnis tertentu. Secara umum semua orang atau industri akan berperan ganda, yaitu sebagai pembeli dan penjual. ${ }^{3}$ Sehingga akhirnya dapat menetapkan harga keseimbangan (harga pasar) dan jumlah yang diperdagangkan. Jadi setiap proses yang mempertemukan antara penbeli dan penjual, maka akan membentuk harga yang disepakati antara penjual dan pembeli.

Secara sederhana pasar dapat dikelompokkan menjadi:

Menurut segi fisiknya, pasar dapat dibedakan menjadi beberapa macam, diantaranya:

1. Pasar tradisional

2. Pasar raya

1 Abdul Aziz, Etika Bisnis Perspektif Islam: Implementasi Etika Islami untuk Dunia Usaha (Bandung, Alfabeta, 2013), Hal. 265-274

2 Eko Suprayitno. Ekonomi Perspektif Islam (Malang: UIN Malang, 2008), Hal. 205

3 Adiwarman A. Karim, Ekonomi Mikro Perspektif Islam (Jakarta: PT. RajaGrafindo Persada, 2015), Hal. 6 
3. Pasar abstrak

4. Pasar swalayan

5. Pasar serba ada

Sedangkan berdasarkan jenis barang yang dijual, pasar dibedakan menjadi beberapa macam di antaranya:

1. Pasar ikan

2. Pasar sayuran

3. Pasar buah-buawahan

4. Pasar barang elektronik

5. Pasar barang perhiasan

6. Pasar barang bangunan

7. Bursa efek, saham dan komoditi

Aktifitas usaha yang dilakukan di pasar pada dasarnya akan melibatkan dua subyek pokok, yaitu produsen dan konsumen. Kedua subyek tersebut masing-masing mempunyai peranan yang sangat besar terhadap pembentukan harga di pasar. ${ }^{4}$

\section{B. Pasar Pada Permulaan Islam}

Islam diturunkan disuatu penduduk yang aktifitas perdagangannya tergolong maju pada saat itu. Bangsa Quraisy di Mekkah sering kali melakukan perdagangan ke Syam dan Yaman. Jalur perdagangann mereka pada saat itu terbentang dari Yaman sampai ke daerah Mediteranian.

Dalam Q.S. Quraisy (106): 1-4 disebutkan:

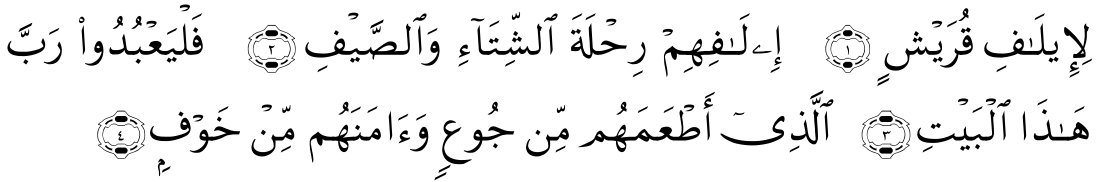

karena kebiasaan orang-orang Quraisy, (1) (yaitu) kebiasaan mereka bepergian pada musim dingin dan musim panas', (2) Maka hendaklah

${ }^{4}$ Eko Suprayitno. Ekonomi Perspektif Islam . Hal. 205-206

5 Orang Quraisy biasa Mengadakan perjalanan terutama untuk berdagang ke negeri Syam pada musim panas dan ke negeri Yaman pada musim dingin. dalam perjalanan itu mereka mendapat jaminan keamanan dari penguasa-penguasa dari negeri-negeri yang dilaluinya. ini adalah suatu nikmat yang Amat besar dari Tuhan mereka. oleh karena itu sewajarnyalah mereka menyembah Allah yang telah memberikan nikmat itu kepada mereka. 
mereka menyembab Tuban Pemilik rumah ini (Ka'bab), (3) yang telab memberi makanan kepada mereka untuk menghilangkan lapar dan mengamankan mereka dari ketakutan, (4). Q.S. Quraisy [106]: 1-4

Menurut beberapa rekan sejarah, perjalanan degang penduduk Quraisy pada saat itu menuju Syam pada saat musim panas dan Yaman pada saat musim dingin. Perjalanan menuju Syam (sekarang masuk dalam wilayah Syiria, Palestina, Yordania dan Lebanon), ataupun Yaman, biasa dilakukan dalam waktu tiga bulan. Mereka melakukan aktifitas ekspor dan impor ke beberapa tempat di atas. Pada awalnya kafilah dagang Quraisy dilepas oleh penduduk Mekkah dengan beberapa unta dan barang dagangan yang berasal dari Mekkah untuk di ekspor ke negara tujuan. ${ }^{6}$ Total lamanya perjalanan mereka adalah satu bulan untuk perjalanan berangkat, satu bulan untuk berdagang dan satu bulan untuk perjalan pulang.

Selain beberapa perjalanan yang dilakukan oleh saudagar arab di era tersebut, ada juga beberapa pasar yang menjadi ajang bagi transaksi yang mereka lakukan, baik dengan cara barter maupun yang lainnya. Diantara pasar tersebut antara lain:

a. Fumatul Jandal (di ujung utara Hijaz, di dekat perbatasan Syiria. Pekan Bisnis ini diadakan setiap tahun pada awal rabiul Awal sampai akhir pekan).

b. Mushaqqar (terletak di suatu kota terkenal di Hijaz, (Bahrain), dimulai pada Jumadil Awal, dan berlangsung sebulan penuh).

c. Sahar (salah satu kota di Oman, pekan bisnis berlangsung di kota ini selama lima hari penuh pada bulan rajab)

d. Dabba (salah satu dari dua kota pelabuhan Oman, biasanya yang berdagang disana saudagar India, Sind, China, dan lain Sebagainya).

e. Shir (Maharab). (disebelah pantai laut Arabia, antara Aden (Yaman) dan Oman, pekan bisnis berlangsung pada awal sampai pertengahan bulan Sya'ban).

f. Aden (Di Yaman pada tangal 1-10 Ramadhan).

g. San'a (di Ibu Kota Yaman, pada 10 sampai akhir Ramadhan).

h. Rabiyah (kota Hadramaut Yaman, pada 15 Dzulqa'dah selama satu bulan penuh).

6 Ika Yunia Fauziah \& Abdul Kadir Riyadi. Prinsip Dasar Ekonomi Islam (Jakrta: Prenadamedia Group, 2014), Hal.197-198 
i. Ukaz (di ujung Najd dekat dengan Taif (masih sekitar Mekkah), pasar ini juga merupakan tempat berkumpulnya banyal suku arab dan juga para penyairnya untuk berbalas syair).

j. Dzul Majaz (dekat Ukaz, diantara Ukas dan Mekkah, berlangsung tanggal 1-7 Dzulhijjah).

k. Mina (selama musim Haji).

1. Nazat (dekat khaibar, pada tangagal 10 sampai akhir bulan Muharram).

m. Hijr (kota di Yamamah, pada tanggal 10 sampai akhir bulan Muharram).

n. Basya' (kota di Syiria, di semenanjung Arabia dan sering didatangi oleh Nabi Muhammad SAW. $)^{7}$

\section{Pasar Pada Masa Rasulullah}

Pada setiap perekonomian, pasar memegang peran penting, termasuk dalam perekonomian masyarakat Muslim pada masa Rasulullah SAW. dan Khulafaur Rasyidin. Rasulullah pada awalnya adalah seorang pebisnis, demikian pula Khulafaur-Rasyidin dan sebagain besar sahabat. Pada usia tujuh tahun nabi Muhammad diajak pamannya, Abu Thalib, melakukan perjalanan perdagangan ke Negeri Syam. Dari sini ilmu-ilmu perniagaan beliau diasah. Kemudain sejalan dengan usianya yang semakin dewasa. Nabi Muhaamd semakin giat berdagang, baik dengan modal sendiri maupun bermitra dengan orang lain. Kemitraan, baik dengan sistem mudharabah mapun musyarakah dianggap cukup populer pada masayarakat Arab pada saat itu. Salah satu mitra bisnisnya adalah Khadijah, seorang wanita pengusaha yang cukup disegani di Mekkah, yang akhirnya menjadi istri Nabi Muhammad SAW. berkali-kali Nabi Muhammad SAW. terlibat urusan dagang kelur negeri (Syam, Syiria,, Yaman, dan lain-lain) dengan membawa modal dari Khadijah.

Nabi Muhammad SAW. seorang pedagang profesional dan selalu menjungjung tingi kejujuran. Beliau mendapat julukan al-amin (yang terpercaya). Setelah menjadi Rasul, Nabi Muhammad SAW. memng tidak lagi menjadi pelaku bisnis secara aktif karena situasi dan kondisi yang

${ }^{7}$ Ika Yunia Fauziah \& Abdul Kadir Riyadi. Prinsip Dasar Ekonomi Islam. Hal. 198-199 
tidak memungkinkan. Pada saat awal perkembangan Islam di Mekkah, Rasulullah SAW. dan masyarakat Muslim mendapat gangguan dan teror yang berat dari masyarakat kafir Mekkah (terumatam suku Quraisy, suku Rasulullah SAW. sendiri) sehingga perjuangan dan dakwah merupakan prioritas. Ketika masyarakat Muslim telah berhijrah ke Madinah, peranan Rasulullah SAW. bergeser menjadi pengawas pasar atau al-Mubtasib. Beliau mengawasi jalannya mekanisme pasar di Madinah agar tetap berlangsung secara Islam.

Pada sasat itu mekanisme pasar sangat dihargai. Rasulullah SAW. menolak untuk membuat kebijakan penetepan harga manakala tingkat harga di Madinah tiba-tiba naik. Selama kenaikan terjadi karena kekuatan permintaan dan penawaran yang murni, yang tidak disertai dengan dorongan monopolistik dan monospolistik, tidak ada alasan bagi Rasulullah SAW. untuk tidak menghormati harga pasar. Pada saat itu para sahabat berkata,

"Wahai Rasulullah, tentukan harga untuk kita! Beliau menjawab, Allah itu sesungubnya penentu harga, penahan, pencurah, serta pemberi rezeki. Aku berharap dapat menemui Tubanku di mana salah seorang kalian tidak menuntutku karena ke zaliman dalam hal darah dan harta."

Dalam hadis tersebut jelas bahwa pasar merupakan hukum alam (sunnatullab) yang harus dijunjung tinggi. Tidak seorangpun secara individual dapat memengaruhi pasar sebab pasar adalah kekuatan kolektif yang telah menjadi ketentuan Allah SWT. ${ }^{8}$

\section{Mekanisme Pasar Dalam Islam}

Ekonomi Islam memandang bahwa pasar, negara, dan individu berada dalam keseimbangan (iqtishad). Pasar dijamin kebebasannya dalam Islam. Pasar bebas menentukan cara-cara produksi dan harga, tidak boleh ada gangguan yang megnakibatkan rusaknya kesimbangan pasar. Akan tetapi, pasar yang berjalan sendiri secara adil (fair) kenyatannya sulit ditemukan.

Konsep istilah pasar dalam Islam dapat dirujuk pada hadis Rasulullah

8 M. Rianto al-Arif. Pengantar Ekonomi Syariah: Teori dan Praktik (Bandung: Pustaka Setiam 2015), Hal. 220-220 
SAW. sebagaimana disampaikan oleh Anas r.a. sehubungan dengan adanya kenaikan harga barang di Kota Madinah. Dari hadis ini terlihat dengan jelas bahwa Islam jauh lebih dahulu (lebih 1160 tahun) mengajarkan konsep mekenisme pasar daripada Adam Smith. Dalam hadis tersebut, jelaskan sebagai berikut:

"Hanya barang dagangan pernah melambung tinggi di Madinah pada zaman Nabi SAW. lalu orang-orang berkata, 'Wahai Rasulullah, harga barang melambung, maka tetapkanlag standar harga untuk kami.'Maka Rasulullah SAW. bersabda, 'Sesunggubnya Allah-lah al-Musa'ir (Yang Maha Menetapkan Harga), al-Qabidh, al-Basith, dan ar-Raziq. Dan sungguh aku benar-benar berharap berjumpa dengan Allah dalam keadaan tidak ada seorangpun dari kalangan yang menuntutku dengan kezaliman dalam masalh darah (nyawa) dan harga'." (H.R. Al-Khamsah, kecuali an-Nasa'i dan disahihkan oleh Ibnu Hibban).

Mekanisme pasar berdasrkan hadis diatas adalah bahwa adanya kebebasan pasar dalam menentukan harga. Harga bergantung pada pasar. Walaupun demikian, Islam tidak menganut harga berdasarkan pasar secara bebas. Islam akan melakukan intervensi ketika terjadi monopoli harga di pasar. Artinya, mekanisme pasar dalam perspektif Islam tidak hanya berdimensi sosial, tetapi juga ada unsur teologis bahwa pasar dikendalikan dan diawasi oleh syariat.

Mekanisme pasar dalam Islam meliputi aspek teologis sampai sosiologis yang terangkaum sebagai berikut:

a. Pembentukan harga sangat dipengaruhi oleh penawaran dan permintaan pasar.

b. Transaksi yang terjadi antara pedagang dan pemebeli adalah transaksi dilandasi oleh faktor suka sama suka.

c. Disuatu pasar yang adil, tidak boleh ada intervensi pasar dari pihak manpun.

d. Pedagang boleh mengambil keuntungan karena keuntungan itu imbalan atas usaha dan resiko, dengan syarat laba tidak berlebihan.

e. Permintaan Islam mencakup hal betikut:

1) Permintaan hanya untuk barang-barang halal dan thayyib.

2) Tidak ada permintaan barang untuk tujuan kemegahan, kemewahan, dan kemubaziran. 
3) Permintaan untuk basic needs masyarakat miskin meningkat karena kewajiban zakat, anjuran infak dan sedekah, dan kewajiban penyediaan kebutuhan dasar oleh negara.

f. Penawaran Islam mencakup hal berikut:

1) Hanya barang-barang halal dan thayyib yang diproduksi.

2) Produksi diprioritaskan untuk memenuhi kebutuhan dasar masyarakat.

3) Keputusan ekonomi tidak hanya mempertimbagkan cost benefi di dunia, tetapi juga di akhirat.

4) Perlinduangan terhadap manusia, sumber daya alam, dan lingkuangan.

g. Market imperfection

Efisiensi pasar tidak tercapai jika pasar tidak sempurna (market imperfection). Hal itu disebabkan oleh:

1) Kekuatan pasar, yang memiliki kekutan yang dapat menentukan harga dan kuantitas keseimbangan.

2) Eksternalitas, aktifitas konsumsi/produksi yang memengaruhi pihak lain, tidak tercermin di pasar.

3) Informasi tidak sempurna, menyebabkan inefisiensi dalam permintaan dan penawaran

h. Dalam Islam, ketidak sempurnaan diatas diakui dan ditambahkan dengan beberapa faktor lain penyebab distori pasar, diantaranya:

1) Rekayasa suply dan demend;

2) Ba'i najasy. Produsen menyuruh pihak memuji produnya atau menawar dengan harga tinggi, sehingga orang akan terpengaruhi;

3) Ihtikar, mengambil keuntungan diatas keuntungan normal dengan cara menahan barang untuk tidak beredar di pasar supaya harganya naik.

4) Tadlis (penipuan), tadlis kuantitas, tadlis kualitas, tadlis harga.

5) Talaqqi ar-rukban: pedagang membeli barang penjual sebelum masuk ke kota.

6) Ghuban faa-hisy, menjual diatas harga pasar. $^{9}$

9 Sukarno Wibowo \& Dedi Supradi. Ekonomi Mikro Islam (Bandung: Pustaka Setia, 2013), Hal. 203-205 


\section{E. Prinsip Dasar Pasar Islami}

Pentingnya pasar sebagai wadah aktifitas tempat jual beli tidak hanya dilihat dari fungsinya secara fisik, namun aturan, norma dan yang terkait dengan masalah pasar. Dengan fungsi di atas, pasar jadi rentan dengan sejumlah kecurangan dan juga perbuatan ketidakadilan yang menzalimi pihak lain. Karena peran penting pasar dan juga rentan dengan dengan hal-hal yang dzalim, maka pasar tidak terlepas dengan sejumlah aturan syariat, yang antara lain terkait dengan pembentukan harga dan terjadinya transaksi di pasar. Dalam istilah lain dapat disebut sebagai mekanisme pasar menurut Islam dan intervensi pemerintah dalam pengendalian harga. Konsep mekanisme pasar dalam Islam dibangun atas prinsipprisnip sebagai berikut:

1. Ar-Ridhaa, yakni segala transaksi yang dilakukan haruslah atas dasar kerelaan antara masing-masing pihak (freedom cuntract). Hal ini sesuai dengan Q.S. An-Nisa' ayat 29:

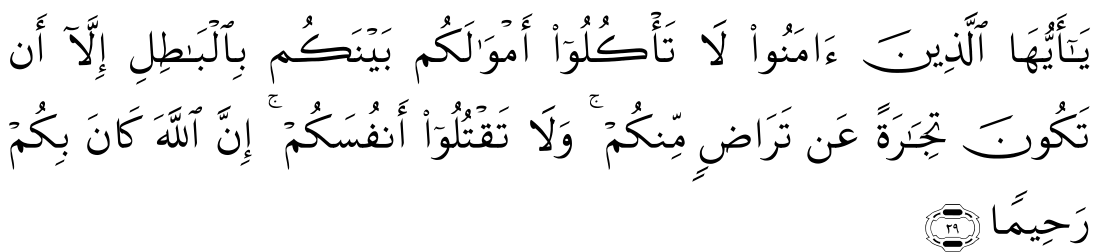

Hai orang-orang yang beriman, janganlab kamu saling memakan harta sesamamu dengan jalan yang batil, kecuali dengan jalan perniagaan yang Berlaku dengan suka sama-suka di antara kamu. dan janganlab kamu membunub dirimu. Sesunggubnya Allab adalah Maha Penyayang kepadamu. (Q.S. An-Nisa' 29)

2. Persaingan sehat (fair competition). Mekanisme pasar akan terhambat bekerja jika terjadi penimbunan (ikbtikar) atau monopoli. Monopoli dapat diartikan, setiap barang yang penahannya akan membahayakan konsumen atau orang banyak.

3. Kejujuran (bonesty), kejujuran merupakan pilar yang sangat penting dalam Islam, sebab kejujuran adalah nama lain dari kebenaran itu sendiri. Islam melarang tegas melakukan kebohongan dan penipuan dalam bentuk apapun. Sebab, nilai kebenaran ini akan berdampak langsung kepada para pihak yang melakukan transaksi dalam dagangan dan masyarakat luas. 
4. Keterbukaan (transparency) serta keadilan (justice). Pelaksanaan prinsip ini adalah transaksi yang dilakukan dituntut untuk berlaku benar dalam pegnungkapan kehendak dan keadaan yang sesungguhnya. ${ }^{10}$

\section{F. Pandangan Ekonomm Muslim}

Pasar telah mendapatkan perhatian cukup memadai dari para ulama klsik, seprti Abu Yusuf, al-Ghazali, Ibnu Khaldun, dan Ibnu Taimiyah. Pemikiran-pemikiran mereka tentang pasar tidak hanya mampu memberikan analisis yang tajam tentang apa yang terjadi pada masa itu.

\section{Mekanisme Pasar menurut Abu Yusuf (731-798 M)}

Pemikiran Abu Yusuf tentang pasar dapat dijumpai dalam bukunya al-Kharaj. Selain membahas prinsip perpajakan dan anggaran negara yang menjadi pedoman kekhalifahan Harun Ar-Rasyid di Baghdad, buku. Tulisan pertamanya menguraikan naik dan turunnya produksi yang dapat memengaruhi harta.

Masyarakat luas pada masa itu memahami bahwa harga suatu barang hanya ditentukan oleh jumlah penawarannya. Dengan kata lain, apabila hanya tersedia sedikit barang, harga akan mahal. Sebaliknya, jika tersedia barang banyak harga akan murah. Mengenai hal ini Abu Yusuf dikutip oleh M.Rianto al-Arif, mengatakan "tidak ada batasan tertentu tentang murah dan mahal yang dapat dipatikanhal tersebut ada yang mengaturnya. Prinsipnya tidak bisa diketahui. Murah karena melimpahnya makanan, demikian juga mahal bukan karena kelangkaan makanan. Kadang-kadang makanan sangat sedikit, tetapi harganya murah." Pernyataan ini menyatakan bahwa harga tidak hanya ditentukan oleh penawaran, tetapi juga permintaan terhadap barang tersebut.

\section{Evolusi Pasar Menurut al-Ghazali (1058-1111 M)}

Al-Ihya 'Ulumuddin karya al-Ghazali juga membahas topik-topik ekonomi, termasuk pasar. Dalam magnum opus-nya ia membicarakan barter dan permasalahannya, pentingnya aktifitas perdagangan dan

${ }^{10}$ Abdul Aziz, Etika Bisnis Perspektif Islam: Implementasi Etika Islami untuk Dunia Usaba Hal. 268-269 
evolusi terjadinya pasar, termasuk bekerjanya kekutan permintaan dan penawaran dalam memengaruhi harga. Dalam terbentuknya pasar menurut al-Ghazali dikutip M.Rianto al-Arif, adalah:

"Dapat saja petani hidup ketika alat-alat pertanian tidak tersedia. Sebaliknya, pandai besi dan tukang kayu hidup, tempat lahan pertanian tidak ada. Akan tetapi, secara alami mereka akan saling memenuhi kebutuhan masing-masing. Dapat saja terjadi tukang kayu membutuhkan makanan, tetapi petani tidak membutuhkan alat-alat tersebut. Keadaan ini menimbulkan masalah. Oleh karena itu, secara alami pula, orang akan terdorong untuk menyediakan tempat penyimpanan alat-alat di satu pihak, dan penyimpanan hasil pertanian dipihak lain. Tempat inilah yang kemudian didatangi pembeli sesuai kebutuhannya masing-masing sehingga terbentuklah pasar. Petani, tukang kayu dan pandai besi yang tidak dapat lengsung melakukan barter juga terdorong pergi kepasar ini. Bila dipasar juga tidak ditemukan orang yang mau melakukan barter, maka ia akan menjual kepada pedagang dengan harga yang relatif murah, untuk kemudian disimpan sebagai persediaan. Pedagang kemudian menjualnya dengan suatu tingkat keuntungan." Hal ini berlaku untuk setiap jenis barang.

Dari pernyataan tersebut, al-Ghazali menyadari kesulitan yang timbul akibat sistem akibat sistem barter yang dalam istilah ekonomi modern disebut double coincidence, dan karena itu diperlukan suatu pasar. Selanjutnya, ia juga memperkirakan kejadian ini akan berlanjut dalam skala yang lebih luas. Mencakup banyak daerah atau negara.

Al-Ghazali tidak menolak kenyataan bahwa mencari keuntungan merupakan motif utama dalam perdagangan. Meskipun demikian, ia memberikan banyak penekanan pada etika dalam bisnis, ketika etika ini diturunkan dari nilai-nilai Islam. Keuntungan yang sesungguhnya merupakan keuntungan yang akan diperoleh di akhirat kelak. Ia juga menyarankan adanya peran pemerintah dalam menjaga keamanan jalur perdagangan demi kelancaran perdagangan dan pertumbuhan ekonomi.

\section{Pasar Menurut Pemikiran Ibnu Taimiyah}

Pemikiran Ibnu Taimiyah mengenai mekanisme pasar dicurahkan melalui bukunya yang sangat terkenal, yaitu al-Hisbah fi'l al-Islam dan 
Majmu' fatawa. Pandangan Ibnu Taimiyah menganai hal ini sebenarnya berfokus pada masalah pergerakan harga yang terjadi pada waktu itu, tetapi ia letakkan dalam kerangka mekanisme pasar. Secara umum ia menunjukkan the beauty of market (keindahan mekanisme pasar sebagai meknisme ekonomi), di samping segala kelemahannya. Ibnu Taimiyah berpendapat bahwa kenaikan harga tidak selalu disebabkan oleh ketidak adilan dari para pedangang dan penjual. Sebagaimana banyak dipahami orang pada waktu itu. Ia menunjukkan bahwa harga merupakan hasil interaksi hukum permintaan penawaran yang berbentuk karena berbagai faktor yang kompleks.

Dalam kitab Fatawa-nya Ibnu Taimiyah juga memberikan penjelasan yang lebih terperinci tentang beberapa faktor yang memengarui permintaan, dan kemudian ditingkat harga. Beberapa faktor terseut menurut Ibnu Taimiyah yang dikutip oleh M.Rianto al-Arif adalah sebagai berikut:

a. Keinginan orang (al-raghabab) terhadap barang sering berbeda-beda. Perbedaan ini dipengaruhi oleh berlimpah atau langkanya barang diminta tersebut (al-matlub). Suatu barang akan lebih sukai apabila ia langka daripada tersedia dalam jumlah yang berlebihan.

b. Jumlah orang yang meminta (demend/tullab) juga memengaruhi barang-barang, selain besar dan kecilnya permintaan. Jika kebutuhan terhadap suatu barang kuat dan berjumlah besar, harha akan naik lebih tinggi dibandingkan dengan kebutuhan lemah dan sedikit.

c. Harga juga akan dipengaruhi oleh kuat atau lemahnya kebutuhan terhadap barang-barang, selain besar dan kecilnya permintaan. Jika kebutuhan terhadap suatu barang kuat dan berjumlah besar, harha akan naik lebih tinggi dibandingkan dengan kebutuhan lemah dan sedikit.

d. Harga juga akan bervariasi menurut kualitas pembeli barang tersebut (al-mu'awid). Jika pembeli merupakan orang kaya dan terpecaya (kredibel) dalam membayar kewajibannya, ia akan memperoleh tingkah harga yang lebih rendah dibandingkan dengan orang yang tidak kredibel (suka menunda kewajiban atau mengingkari).

e. Tingkat harga juga dipengaruhi oleh jenis (uang) pembayaran yang digunakan dalam transaksi jual beli. Jika uang yang digunakan adalah uang yang diterima luas, kemungkinan harga akan lebih rendah jika 
dibandingkan dengan menggunakan uang yang kurang luas yang diterima.

f. Tujuan dari suatun trasnsaksi harus menguntungkan penjual dan pembeli. Jika pembeli memiliki kemampuan untuk membayar dan dapat memenuhi semua janjinya, transaksi akan lebih lancar dibandingkan dengan pembeli yang tidak memiliki kemapuan membayar dan mengingkari janjinya. Tingkat harga barang yang yang lebeh nyata (secara fisik) akan lebih rendah dibandingkan dengan yang tidak nyata.

g. Kasus yang sama dapat diterapkan kepada orang yang menyewakan suatu barang. Kemungkinan ia berada pada posisi sedemikian rupa sehingga penyewa dapat memperoleh manafaat dengan tampa (tambahan) biaya apapun. Walaupun demikian, kadang-kadang penyewa tidak dapat memperoleh manfaat ini jika tampa tambahan biaya.

\section{Mekanisme Pasar Menurut Pemikiran Ibnu Khaldun (1332- $1406 \mathrm{M}$ )}

Pemikran Ibnu Khaldun tentang pasar termuat dalam buku alMuqaddimah.menurut Ibnu Khaldun dikutip M. Rianto al-Arif mengataka, Ia membagi barang-barang menjadi dua katagori, yaitu barang pokok dan barang barang mewah. Menurutnya, jika suata kota berkembang dan jumlah penduduknya semakin banyak, harga barang-branga pokok akan menurun, sedangkan harga barang mewah akan menaik. Hal ini siebabkan oleh meningkatnya penawaran bahan pangann dan batang pokok lainnya sebab barang ini sangat penting dan dibutuhkan oleh setiap orang sehinga pengadaannya akan diperioritaskan. Adapan harga barang mewah akan naik sejalan dengan meningkatnya gaya hidup yang mengakibatkan penignkatan permintaan barang mewah.

Ibnu Khaldun dikutip M. Rianto al-Arif, juga menjelaskan pengaruh permintaan dan penawaran terhadap tingkat harga. Secara lebih rinci ia menjelaskan pengaruh persaingan diantara para konsumen dan meningkatnya biaya-biaya akibat perpajakan dan pungutan lain terhadap tingkat harga.

Ibnu Khaldun sangat menghargai garga yang terjadi dalam pasar 
bebas, tetapi ia tidak mengajukan saran-saran kebijakan pemerintah untuk mengelola harga . ia lebih banyak mefokuskan pada faktor-faktor yang mempengaruhi harga. Hal ini berbeda dengan Ibnu Taimiyah, yang dengan tegas menentang intervensi pemerintah selama pasar berjalan bebas dan normal. ${ }^{11}$

\section{A. Mekanisme Keadilan Pasar Islami}

Aktifitas di pasar identik dengan berdagang. Berdagang adalah aktifitas yang paling umum dilakan di pasar. Konsep Islam memahami bahwa pasar dapat berperan efektif dalam kehidupan ekonomi bila persaingan bebas dapat berlaku secara efektif. Pasar tidak mengharapkan adanya intervensi dari pihak manapun. Menurut Ibnu Taimiyah membatasi keabsahan pemerintah dalam menetapkan kebijakan intervensi pada empat situasi dan kondisi sebagai berikut:

1. Kebutuhan masyarakat atau hajat orang banyak akan sebuah komoditas.

2. Terjadi kasus monopoli (penimbunan).

3. Terjadi pendistribusian pada satu penjual saja.

4. Para pedagang melakukan transaksi di antara mereka sendiri dengan harga di bawah harga pasar.

Kegiatan berdagang di pasar telah lama di kenal oleh manusia. Kegiatan ini di lakukan oleh setiap orang untuk keluar masuk pasar. Sehingga aktifitas perdagangan di pasar dapat merupakan kebebasan berekonomi. Kebebasan ekonomi yang berdasarkan pada ajaran Islam yang meliputi pertanggungjawaban dan kebebasan. Atau kebebasan yang berkaitan erat dengan pertanggungjawaban. Prinsip pertanggung jawaban:

1. Setiap orang dihisap secara individu.

2. Tidak ada konsep dosa keturunan dan mempertanggungjawabkan kesalahan orang lain.

3. Tidak ada perantaraan dalam hubungan langsung dengan Allah.

4. Setiap individu berhak untuk berpedoman langsung dengan sumbersumber hukum Islam (al-Qur;an dan Hadis)

5. Islam sudah sepurna dalam berbagai aspek kehidupan.

${ }^{11}$ M. Rianto al-Arif. Pengantar Ekonomi Syariah: Teori dan Praktik. Hal. 222-230 
Dengan demikian dapat dijelaskan bahwa mekanisme pasar merupakan sistem yang cukup efisien dalam memberlakukan harga yang adil dan bahkan untuk mengalokasikan faktor-faktor produksi dan mendorong kegiatan ekonomi. Hal ini disebabkan karena mekanisme pasar memiliki beberapa kelebihan, seperti pasar dapat membrikan informasi yang tepat, pasar dapat merangsang pelaku usaha untuk melakukan kegiatan ekonomi, pasar mendorong penggunaan faktorfaktot produksi serta pasar memberikan kebebasan yang tinggi kepada masyarakat untuk melakuan kegiatan ekonomi.

Disamping kelebihan-kelebihan itu, mekanisme pasar juga memiliki beberpa kelemahan, seperti adanya kebebasan yang tidak terbatas akan menindas golongan-golongan tertentu, kegiatan ekonomi tidak stabil, munculnya kekuatan monopoli, tidak mampu menyediakan beberapa jenis barang secara efisien serta dampak eksternalitas yang merugikan.

Salah satu dari kelemahan mekanisme pasar, yaitu monopoli. Islam dengan tegas melarang praktek monopoli dan semua cara kepalsuan untuk mendongkrak harga demi memperbesar keuntunga. Pelarangan ini kerena pada umumnya, monopoli menetapkan harga yang lebih tinggi dari hasil produksinya.

Dalam ekonomi Islam, praktek ekonomi apapun yang menjadi sebab terjadinya konsentrasi kekayaan pada segelintir orang dilarang. Konsentrasi kekayaan pada sebagian orang akan menyebabkan distribusi kekayaan terhambat, sehingga terjadi ketimpangan dan ketidakmerataan. Begitu halnya dengan praktik monopoli, praktik ini dilarang karena jelas merusak mekanisme pasar.

Mekanisme pasar memiliki arti khusus dalam sistem ekonomi Islam. Teori harga dalam Islam melarang setiap bentuk pemerasan, baik dari pihak produsen maupun konsumen. Oleh karena itu, bentuk pemerasan dalam mekanisme pasar dalam Islam merupakan bentuk perbuatan tercela, bukan saja pada dimensi duniawi tapi juga bentuk uhkrawi.

Dalam ekonomi konvensional, persaingan sehat yang berbentuk struktur pasar atau mekanisme pasar dimanifestasikan dengan pasar persaingan sempurna. Ciri-ciri pasar persaingan sempurna meliputi; 1) jumlah penjual dan pembeli banyak, 2) produk yang dijual homogen, 3) adanya kekebasan perusahaan untuk keluar masuk pasar, 4) harga ditentukan oleh pasar. Persyaratan pasar persaiangan sempurna dalam 
sistem ekonomi konvensional terletak pada kebebasan pasar (free market). Namun demikian, model pasar persaiangan sempurna yang kemudian diperbandingkan dengan model pasar monopoli terdapat kelemahan yang mendasar. Menurut Hidayat Nataatmadja dikutip oleh Abdul Aziz, kelemahan-kelemahan model persaiangan ini terletak pada:

1. Asumsi bahwa kurva biaya perusahaan monopolis sama dengan kurva biaya seorang pengusaha guren yang menghasilkan komoditi yang sama, adalah seperti mengangap semut dan gajah itu sama karena sama-sama binatang, sehinga keduanya keduanya bisa diperbandingkan.

2. Dalam praktik tidak ada monopoli maupun ahli ekonomi yang mengetahui pesris bagaimana bentuk kurva biaya marginal, apalagi dengan terus-menerus muncul inovasi baru.

3. Kedudukan final pasar bersaingan sempurna sama sekali bukan keadaan ideal, melainkan keadaan involusi yang dewasa.

Untuk itu maka, Islam memandang bahwa mekanisme pasar setidaknya harus dapat:

1. Meyelesaikan masalah ekonomi produksi dan distribusi secara merata sebagai tujuan mekanisme pasar.

2. Para konsumen berperilaku sesuai dengan ajaran Islam.

3. Campur tangan negara diperlukan sejauh bermanfaat bagi kepentingan banyak dan melindungi kepentingan umum ${ }^{12}$.

\section{KESIMPULAN}

Ekonomi Islam memandang bahwa pasar, negara, dan individu berada dalam keseimbangan (iqtishad). Pasar dijamin kebebasannya dalam Islam. Pasar bebas menentukan cara-cara produksi dan harga, tidak boleh ada gangguan yang mengakibatkan rusaknya kesimbangan pasar. Akan tetapi, pasar yang berjalan sendiri secara adil (fair) kenyatannya sulit ditemukan.

Mekanisme pasar adalah bahwa adanya kebebasan pasar dalam menentukan harga. Harga bergantung pada pasar. Walaupun demikian, Islam tidak menganut harga berdasarkan pasar secara bebas. Islam akan

${ }^{12}$ Abdul Aziz, Etika Bisnis Perspektif Islam: Implementasi Etika Islami untuk Dunia Usaha. Hal. 265-274 
melakukan intervensi ketika terjadi monopoli harga di pasar. mekanisme pasar dalam perspektif Islam tidak hanya berdimensi sosial, tetapi juga ada unsur teologis bahwa pasar dikendalikan dan diawasi oleh syariat Mekanisme pasar dalam Islam meliputi aspek teologis sampai sosiologis 


\section{Daftar Pustaka}

Al-Arif M. Rianto, 2015. Pengantar Ekonomi Syariah: Teori dan Praktik: Bandung: Pustaka Setia

Aziz, Abdul, 2013. Etika Bisnis Perspektif Islam: Implementasi Etika Islami untuk Dunia Usaha: Bandung, Alfabeta

Fauziah, Ika Yunia \& Riyadi, Abdul Kadir, 2014. Prinsip Dasar Ekonomi Islam: Jakrta: Prenadamedia Group

Islam, M. H. 2016. Ibnu Taimiyah and His Concept of Economy. Iqtishoduna: Jurnal Ekonomi Islam, 5(1), 15-33.

Karim, A. Adiwarman, 2015. Ekonomi Mikro Perspektif Islam: Jakarta: PT. RajaGrafindo Persada

Suprayitno, Eko, 2008 . Ekonomi Perspektif Islam: Malang: UIN Malang

Wibowo, Sukarno \& Supriad, Dedi Sup, 2013. Ekonomi Mikro Islam. Bandung: Pustaka Setia 